\title{
Discometra luberonensis sp. nov. (Crinoidea, Himerometridae), a new feather star from the Late Burdigalian
}

\author{
Marc ELÉAUME ${ }^{1, *}$, Michel ROUX $^{2} \&$ Michel PHILIPPE $^{3}$ \\ 1,2 UMR7205 ISYEB, Muséum national d'histoire naturelle, CNRS, Sorbonne Université, EPHE, \\ Université des Antilles, CP 51, 57 rue Cuvier, 75231 Paris Cedex 05, France. \\ ${ }^{3}$ Centre "Louis Lortet" de conservation et d'étude des collections (Musée des Confluences, Lyon) \\ 13A, rue Bancel - 69007 Lyon, France. \\ *Corresponding author: marc.eleaume@mnhn.fr \\ ${ }^{2}$ Email: mich.roux51@gmail.com \\ ${ }^{3}$ Email: mipauphi@wanadoo.fr \\ ${ }^{1}$ urn:1sid:zoobank.org:author:66D3D76C-62AC-4B6D-9A3B-2A2665EA4DB9 \\ ${ }^{2}$ urn:lsid:zoobank.org:author:7E6DF41A-A61D-48B2-99EE-A43021E3E739 \\ ${ }^{3}$ urn:lsid:zoobank.org:author:457B0CA9-3D41-45FC-A20B-3090B2FA8F18
}

\begin{abstract}
Most fossil feather stars are known only from the centrodorsal often connected to the radial circlet. This is the case for Discometra rhodanica (Fontannes, 1877), the type species of the genus Discometra, collected from the Late Burdigalian of the Miocene Rhône-Provence basin (southeastern France). The quarries operating in this area have exposed layers from the Late Burdigalian on the northern flank of the Lubéron anticline near Ménerbes (basin of Apt, Vaucluse, southeastern France). These layers contain exceptionally well-preserved echinoderms, among which are three specimens of a feather star with cirri and arms still connected to the centrodorsal. They are attributed to a new species: Discometra luberonensis sp. nov. (Himerometridae). The number of arms can reach 60, as in extant species of the genus Himerometra, but the pattern of arm divisions is closer to that of the genus Heterometra, which has no more than 45 arms in extant species. Discometra luberonensis sp. nov. differs from $D$. rhodanica by the characters of its centrodorsal. Here we redescribe the centrodorsal and radial circlets of $D$. rhodanica based on previously and newly collected specimens. We designate a neotype for $D$. rhodanica, because the holotype is considered lost. Affinities between Discometra, Himerometra and Heterometra are discussed.
\end{abstract}

Keywords. Crinoidea, Himerometridae, Discometra, Miocene, southeastern France.

Eléaume M., Roux M. \& Philippe M. 2020. Discometra luberonensis sp. nov. (Crinoidea, Himerometridae), a new comatulid from the Late Burdigalian. European Journal of Taxonomy 729: 121-137.

https://doi.org/10.5852/ejt.2020.729.1193

\section{Introduction}

The family Himerometridae A.H. Clark, 1908 consists only of extant species, except for the genus Discometra Gislén, 1924, which dates to the Miocene, and is only known from centrodorsals and the 
radial circlet. Gislén (1924: 180) erected this genus "at least temporarily" to group together Miocene species with insufficiently known centrodorsals and radial circlets, but differing from the other extant genera distinguished by A.H. Clark $(1909,1918)$. Isolated ossicles and calices found in the Eocene and Oligocene had been attributed to the extant genus Himerometra A.H. Clark, 1907, and Discometra was attributed to Himerometridae (Sieverts-Doreck 1961; Strimple \& Mapes 1984; Rasmussen 1978; Hess \& Messing 2011). Later, Taylor et al. (2017) removed all fossil species from Himerometra and assigned them to Himerometroidea incertae sedis.

On the northern flank of the Lubéron anticline (Apt basin, Vaucluse, SE France; Fig. 1), bioclastic limestones with the pectinid bivalve Gigantopecten restitutensis (Fontannes, 1884) dated to the Late Burdigalian contain accumulations of spectacular fossiliferous slabs exposed during the exploitation of quarries located on the Ménerbes-Lacoste Plateau (Bongrain 2013). The shells of G. restitutensis, most often with connected valves, and the tests of the echinoid Tripneustes planus (Agassiz, 1840) preserved with their spines and dental apparatus are the most abundant taxa and are associated with complete large sea stars and brittle stars. These accumulations correspond to mass sediment flows on the unstable slopes of the northern flank of the Lubéron anticline. They led to the almost instantaneous burial of benthic

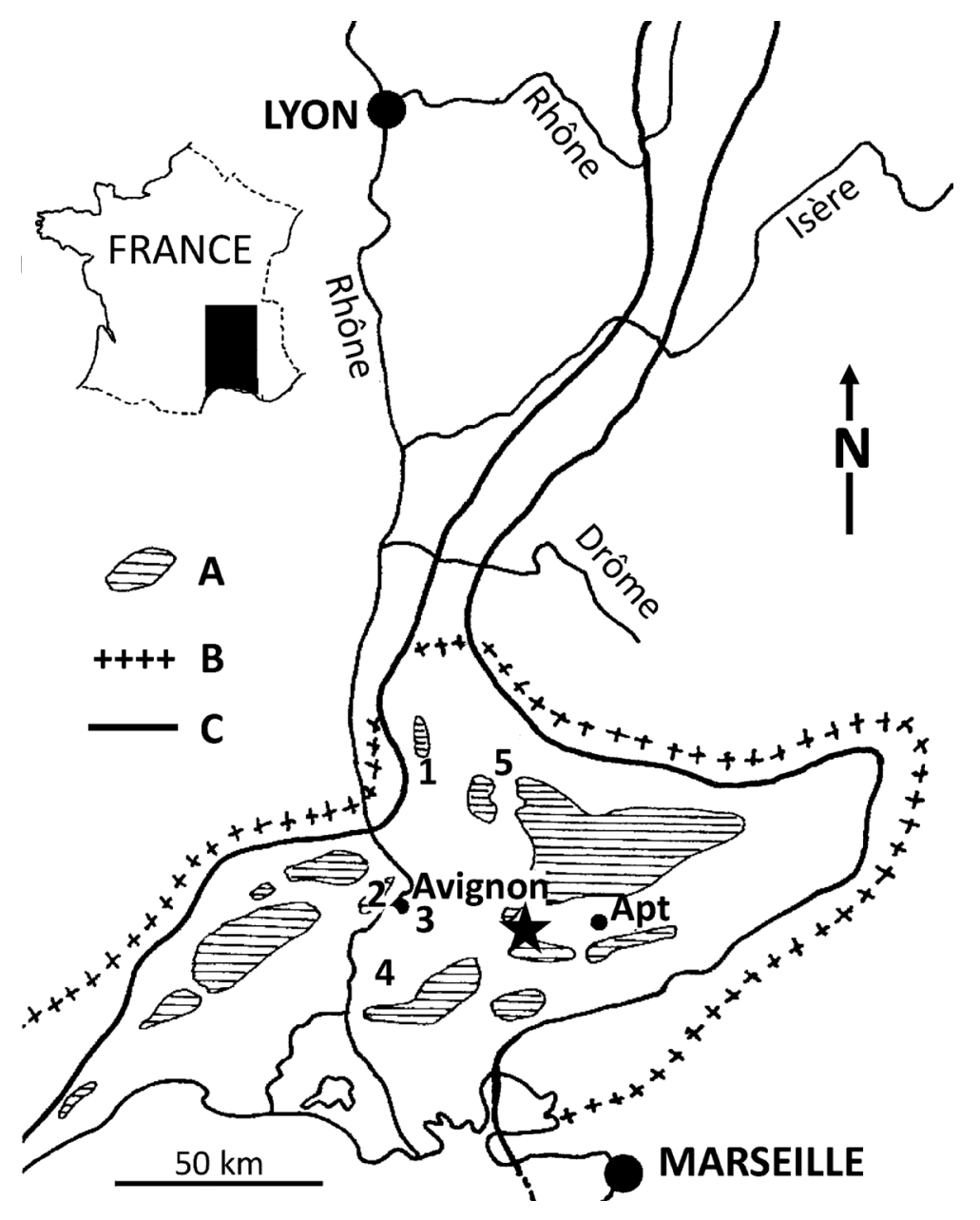

Fig. 1. The Miocene Rhône-Provence Gulf (modified from Philippe 1998: fig.1). A = submarine or emerging shoals; B = limit of the Rhône-Provence Gulf; C = estimated limit of the Burdigalian transgression. Sites with Discometra Gislèn, 1924 cited in the text are indicated as follows: black star = Ménerbes-Lacoste Plateau; 1 = Bollène; 2 = Les Angles; 3 = Caumont-sur-Durance (Picabrier); 4 = Notre-Dame du Château; 5 = Entrechaux. 
ELÉAUME E. et al., A new species of feather star (Echinodermata: Crinoidea) from the Miocene

communities, with the result that some feather stars were exceptionally preserved. Centrodorsals, often with their radial circlet, were previously collected in the Late Burdigalian of the Rhône-Provence basin (Fontannes 1880; de Loriol 1897; Pellat 1897; Nicolas 1898; Joleaud 1907; Valette 1928; Philippe 1974). Discometra rhodanica (Fontannes, 1877) is the species that reaches the largest size.

Here we describe three specimens of a new species of Miocene feather star with arms connected to the calyx and with crowns well enough preserved to allow description of arm organization. The specimens were collected from Ménerbes in deposits that correspond to a thermal maximum at the Late BurdigalianLanghian boundary (Demarcq 1984). In the Rhône-Provence Gulf, the Miocene Sea transgressed over a deformed and eroded substratum, leaving numerous submarine or emerging shoals separated by strongly incised valleys (Demarcq 1970; Besson 2005) (Fig. 1). Such a setting agrees with the distribution of extant species of Himerometridae, which are mainly found in shallow-water environments in the tropical western Pacific and northern Indian Ocean (Hess \& Messing 2011). To determine whether or not our three specimens belong to D. rhodanica, we re-examined reference specimens in the collections of the museums in Lyon, Avignon and Saint-Rémy de Provence, and well-preserved specimens recently collected in Caumont-sur-Durance (Picabrier site).

\section{Material and methods}

The specimens of D. luberonensis sp. nov. (Fig. 2A-F) are preserved on three limestone slabs rich in echinoderms and Gigantopecten extracted from the Soubeyran quarry in Ménerbes and conserved at the Centre "Louis Lortet" de conservation et d'étude des collections (Musée des Confluences, Lyon). The slab MHNL 20.056151 (collected by R. Lacombe, now added to M. Philippe's collection) was illustrated by Bongrain (2013: fig. 9b). Following the expansion of urbanization in the last decades, most of the ancient outcrops where $D$. rhodanica had been collected are no longer accessible (Bollène, Les Angles, Caumont-sur-Durance) with the exception of Notre-Dame du Château between Saint-Etienne du Grès and Saint-Rémy de Provence (northern slope of the Alpilles). It was therefore important to locate the specimens used for the first descriptions of the species. Those collected by E. Pellat and described by him (Pellat 1897) and de Loriol (1897) are housed in the collection of the Musée des Alpilles in SaintRémy de Provence. Those coming from ancient quarries of the Les Angles Plateau (west of Avignon) and described by Nicolas (1898) belonged to his own collection deposited in the palaeontological collection of the University Claude Bernard, Lyon I, and in private collections including the Châtelet's collection, which has been partly deposited in the Musée Requien, Fondation Calvet (Musée d'Histoire naturelle) in Avignon. However, we were unable to find the calyx figured by Nicolas (1898: 403, fig. 1), or those figured by Fontannes (1880: pl. 2, figs 10-11). As a consequence, we consider them as lost. Measurements of these lost specimens (Table 2) are deduced from the original publications. The three calices from the Picabrier outcrops exposed in Caumont-sur-Durance were collected by one of us (MP). This site was studied by Ulysse (1968). The centrodorsal comes from the 'Ferme Pie' outcrops exposed near Entrechaux (Philippe 1974). The studied specimen of Himerometra robustipinna (Carpenter, 1881) (Fig. 2G) was collected during the Salomon 1 cruise (DW 1822, 951.08' S, 16051.8' E, depth 51-54 $\mathrm{m}$ ) and the studied specimen of Heterometra savignii (Müller, 1841)(Fig. 2H) during the R.P. Dollfus expedition to the Gulf of Suez. They are housed in the zoological collection of the Muséum national d'histoire naturelle in Paris.

The pictures in Figs 3, 5-6 were taken using a scanning electron microscope (SEM) type JEOL-840A at $15 \mathrm{kV}$ (Electron Microscopy Platform of the Muséum national d'histoire naturelle in Paris). Ossicles from extant species were dissociated after a 12-hour bath in sodium hypochlorite, washed with distilled water and dried. All ossicles observed using SEM were coated with a colloidal platinum solution. 
Table 1. List of fossil and extant specimens examined. In the 'Remarks' column, the names of the collectors are indicated (except for extant species and type specimens, see text). $\mathrm{CD}=$ centrodorsal; $\mathrm{RR}=$ radial circlet.

\begin{tabular}{|c|c|c|c|c|c|c|}
\hline Taxon & Collection & Catalog \# & Locality & Preservation & Figure & Remarks \\
\hline $\begin{array}{l}\text { Heterometra } \\
\text { savignii }\end{array}$ & MNHN & MNHN-IE-2016-1381 & W-Pacific & complete & $2 \mathrm{H}$ & Recent \\
\hline $\begin{array}{l}\text { Himerometra } \\
\text { robustipinna }\end{array}$ & MNHN & MNHN-IE-2012-862 & W-Pacific & complete & $2 \mathrm{G}$ & Recent \\
\hline Unidentified & MASR & 2020.5021 & N.D. Château & RR & $5 \mathrm{D}-\mathrm{E}$ & Pellat \\
\hline Comatulidae & MHNL & 20.062689 & Entrechaux & $\mathrm{CD}$ & $5 \mathrm{C}$ & Philippe \\
\hline $\begin{array}{l}\text { Discometra } \\
\text { rhodanica }\end{array}$ & UCBL & $200025 a$ & Les Angles & calyx & - & Nicolas \\
\hline $\begin{array}{l}\text { Discometra } \\
\text { rhodanica }\end{array}$ & MRA & 3.000 .349 & Les Angles & calyx & - & Châtelet \\
\hline $\begin{array}{l}\text { Discometra } \\
\text { rhodanica }\end{array}$ & MRA & 3.000 .348 & Les Angles & calyx & - & Châtelet \\
\hline $\begin{array}{l}\text { Discometra } \\
\text { rhodanica }\end{array}$ & UCBL & $200025 b$ & Les Angles & $\mathrm{CD}$ & - & Nicolas \\
\hline $\begin{array}{l}\text { Discometra } \\
\text { rhodanica }\end{array}$ & MASR & 2020.5011 & N.D. Château & calyx & $5 \mathrm{~A}-\mathrm{B}$ & neotype \\
\hline $\begin{array}{l}\text { Discometra } \\
\text { rhodanica }\end{array}$ & MHNL & 20.062686 & Picabrier & calyx & $6 \mathrm{~A}$ & Philippe \\
\hline $\begin{array}{l}\text { Discometra } \\
\text { rhodanica }\end{array}$ & MHNL & 20.062687 & Picabrier & calyx & $6 \mathrm{C}-\mathrm{D}$ & Philippe \\
\hline $\begin{array}{l}\text { Discometra } \\
\text { rhodanica }\end{array}$ & MHNL & 20.062688 & Picabrier & calyx & $6 \mathrm{~B}$ & Philippe \\
\hline $\begin{array}{l}\text { Discometra } \\
\text { luberonensis } \\
\text { sp. nov. }\end{array}$ & MHNL & 20.056148 & Ménerbes & complete & $2 \mathrm{C}-\mathrm{D}$ & paratype \\
\hline $\begin{array}{l}\text { Discometra } \\
\text { luberonensis } \\
\text { sp. nov. }\end{array}$ & MHNL & 20.056151 & Ménerbes & complete & $2 \mathrm{E}-\mathrm{F}$ & paratype \\
\hline $\begin{array}{l}\text { Discometra } \\
\text { luberonensis } \\
\text { sp. nov. }\end{array}$ & MHNL & 20.062682 & Ménerbes & complete & $2 \mathrm{~A}-\mathrm{B}$ & holotype \\
\hline
\end{tabular}

\section{Repositories}

MHNL = Centre "Louis Lortet" de conservation et d'étude des collections, Musée des Confluences (formerly Muséum d'Histoire naturelle de Lyon), Lyon

MASR $=$ Musée des Alpilles, Saint-Rémy de Provence

MRA $=$ Musée Requien, Fondation Calvet, Avignon

MNHN = Muséum national d'histoire naturelle (zoological collection), Paris

UCBL = Université Claude Bernard (palaeontological collections), Lyon I 
ELÉAUME E. et al., A new species of feather star (Echinodermata: Crinoidea) from the Miocene

Table 2. Quantitative characters of calices attributed to Discometra Gislèn, 1924 from the Miocene of the Rhône-Provence basin. D1 = maximum diameter of centrodorsal; D2 = diameter of aboral cirrus-free depression; D3 = diameter of adoral cavity limited by radial circlet; Hca = calyx height (centrodorsal + radial circlet); Hcd = average of centrodorsal height. Specimens ordered by size at each site (D1 used as the age index). Specimen UCBL 200025b is an isolated centrodorsal. Parameters in mm. Ratios in bold type: $\mathrm{D} 2 / \mathrm{D} 1$ = index of cirrus disappearance on aboral centrodorsal face; $\mathrm{D} 3 / \mathrm{D} 1=$ degree of opening of the adoral calyx cavity; $\mathrm{Hcd} / \mathrm{Hca}=$ relative centrodorsal height; $\mathrm{Hcd} / \mathrm{D} 1=$ degree of centrodorsal flattening. * = neotype of D. rhodanica (Fontannes, 1877) (from de Loriol 1897: fig. 8); ** = holotype of $D$. luberonensis sp. nov. See Table 1 and text for more information on specimens.

\begin{tabular}{|c|c|c|c|c|c|c|c|c|c|c|}
\hline Specimen & Location & D1 & D2 & D2/D1 & D3 & D3/D1 & Hed & Hca & Hed/Hea & D1/Hed \\
\hline \multicolumn{11}{|c|}{ Discometra rhodanica } \\
\hline $\begin{array}{l}\text { Fontannes } \\
\text { 1880: fig. } 10\end{array}$ & Bollène & $\sim 13.0$ & $\sim 7.2$ & $\sim 0.56$ & $\sim 3.0$ & $\sim 0.23$ & $\sim 2.0$ & $\sim 4.5$ & $\sim 0.44$ & $\sim 6.67$ \\
\hline $\begin{array}{l}\text { Fontannes } \\
\text { 1880: fig. } 11\end{array}$ & Bollène & $\sim 8.5$ & $?$ & - & $\sim 2.8$ & $\sim 0.33$ & $\sim 1.8$ & $\sim 5.0$ & $\sim 0.36$ & $\sim 4.76$ \\
\hline $\begin{array}{l}\text { Nicolas 1898: } \\
\text { fig. } 1\end{array}$ & Les Angles & 14.3 & $?$ & $?$ & $<5.0$ & $<0.35$ & $\sim 3.8$ & $>7.5$ & $<0.51$ & $\sim 3.76$ \\
\hline UCBL 200025a & Les Angles & 14.0 & $<8.2$ & $<0.58$ & 3.0 & 0.21 & 2.75 & 6.2 & 0.44 & 5.00 \\
\hline MRA 3.000.349 & Les Angles & 13.4 & 6.8 & 0.51 & $<3.7$ & $<0.28$ & 2.8 & 5.8 & 0.48 & 4.78 \\
\hline UCBL 200025b & Les Angles & $>12.0$ & 5.0 & $<0.42$ & - & - & 2.65 & - & - & $<4.54$ \\
\hline MRA 3.000.348 & Les Angles & 7.85 & - & - & - & - & 1.8 & $>4.0$ & $<0.45$ & 4.39 \\
\hline $\begin{array}{l}\text { MASR } \\
2020.5011 *\end{array}$ & $\begin{array}{l}\text { N.D. } \\
\text { Château }\end{array}$ & 8.3 & 2.1 & 0.3 & 1.9 & 0.23 & 2.2 & 4.6 & 0.48 & 3.85 \\
\hline $\begin{array}{l}\text { MHNL } \\
20.062686\end{array}$ & Picabrier & 12.0 & 7.5 & 0.62 & $>2.7$ & $>0.22$ & 2.6 & $?$ & $?$ & 4.61 \\
\hline $\begin{array}{l}\text { MHNL } \\
20.062687\end{array}$ & Picabrier & 9.9 & 3.25 & 0.33 & 2.6 & 0.26 & 2.2 & 4.9 & 0.45 & 4.50 \\
\hline $\begin{array}{l}\text { MHNL } \\
20.062688\end{array}$ & Picabrier & 7.7 & 2.1 & 0.27 & 1.75 & 0.23 & 1.8 & 4.4 & 0.41 & 4.23 \\
\hline \multicolumn{11}{|c|}{ Discometra luberonensis sp. nov. } \\
\hline $\begin{array}{l}\text { MHNL } \\
20.056148\end{array}$ & Ménerbes & 13.5 & 8.55 & 0.63 & $?$ & - & 2.5 & $?$ & - & 5.26 \\
\hline $\begin{array}{l}\text { MHNL } \\
20.056151\end{array}$ & Ménerbes & 12.5 & 8.3 & 0.66 & $?$ & - & 1.9 & $?$ & - & 6.67 \\
\hline $\begin{array}{l}\text { MHNL } \\
20.062682 * *\end{array}$ & Ménerbes & 11.7 & 6.3 & 0.54 & $?$ & - & 2.8 & $?$ & - & 4.18 \\
\hline
\end{tabular}

\footnotetext{
Abbreviations

I, II, III, IV, V = brachitaxis position from proximal (I) to more distal (V)

Ibr2ax $\quad=$ first brachitaxis composed of 2 brachials of which the second is an axillary

br $\quad=$ brachial (when used without prefix refers to free arm; otherwise refers to a given brachial in a brachitaxis)

$=$ synarthry (e.g., br1-2 refers to a synarthry between brachials 1 and 2 of free arm)

$+\quad=\quad$ syzygy (e.g., br3 +4 refers to a syzygy between brachials 3 and 4 of free arm)

c $\quad=\operatorname{cirral}($ e.g., c1-c5 indicate cirrals 1 to 5$)$

$\mathrm{P}_{\mathrm{II}} \quad=$ exterior pinnule on the first or second ossicle of brachitaxis II (e.g., $\mathrm{P}_{\text {II }}$ on IIbr2)
} 


\title{
Results
}

\author{
Class Crinoidea Miller, 1821 \\ Subclass Articulata Zittel, 1879 \\ Order Comatulida A.H. Clark, 1908 \\ Superfamily Himerometroidea A.H. Clark, 1908 \\ Family Himerometridae A.H. Clark, 1908
}

\section{Remarks}

Hess \& Messing (2011) placed Himerometridae within the superfamily Mariametroidea A.H. Clark, 1909 (later changed to Himerometroidea by Taylor et al. 2017) in which rod-shaped basals are absent. All genera in Himerometridae (Heterometra A.H. Clark, 1909, Himerometra, Craspedometra A.H. Clark, 1909, Amphimetra A.H. Clark, 1909), except Discometra, show coelomic grooves on the adoral side of centrodorsal. Amphimetra has multiple radiate coelomic grooves while Heterometra, Himerometra and Craspedometra show Y-shaped grooves with more or less wide branches. In Discometra, such Y-shaped features are present as canals included in the stereom and located just beneath the surface of the proximal facet of radials (Fontannes 1880; Sieverts-Doreck 1961). As a consequence, coelomic grooves are absent from the adoral surface of the centrodorsal. In Himerometra, the aboral facet of each radial displays a pair of wide grooves running in parallel in the inner part and diverging in a $Y$ shape in the outer part; this feature is also visible on the oral side of the centrodorsal (Fig. 3A). Coelomic groove patterns are very similar in Himerometra (Fig. 3A) and Discometra (Fig. 4) but differ markedly in each of the other genera (Rasmussen 1978: figs 593-594). The numerous radiating coelomic grooves (A.H. Clark 1915) distinguish Amphimetra the most from the other genera, and Hemery (2011), Summers \& Rouse (2014) and Taylor et al. (2017) questioned its attribution to Himerometridae. In Himerometra, the general shape of the centrodorsal varies from hemispherical to almost discoidal. The insertions of cirri on the centrodorsal have a very variable aspect on the same individual, with or without a slight rectangular transverse relief (Fig. 3B). The radial circlet delimits a more or less wide adoral cavity whose flanks corresponding to the inner face of the radials are sculpted by strong vermiculate figures (Fig. 3C). The distal articular facet of the radials is sub-trapezoidal, the internal (adoral) ligamentary areas, with no distinguishable limit adorally, are separated by a large depression, and the muscular areas are reduced and nearly inconspicuous (Fig. 3D).

\section{Stratigraphical range}

Miocene-Recent (Western Pacific), possibly since the Eocene.

\section{Type species}

Genus Discometra Gislèn, 1924

Eugeniacrinus? rhodanicus Fontannes, 1877.

\section{Emended diagnosis}

Centrodorsal hemispherical to low hemispherical or discoidal; cirrus-free aboral apex concave or flattened; adoral side with inter-radial ridges; cirrus sockets with or without low transverse rectangular ridge and closely placed, often in 3 (rarely 5) irregular rows. Cirrals without aboral spines. Radials with internal, Y-shaped coelomic canals just beneath proximal surface; radial circlet nearly equal to or lower and narrower than centrodorsal; interarticular ligament fossae large, separated by wide midradial area. Rod-shaped basals absent. Numerous arms, up to about 60; brachitaxes with 2 or 4 ossicles ( 2 frequent beyond tertibrachitaxis); ligamentary synarthry at br1-2; syzygy with radiating crenularium at br $3+4$; ligamentary articulations irregularly placed beyond br5. 


\section{Remarks}

Gislén (1924) designated D. rhodanica as the type species of the genus, so it is important to clarify and complete the description with the new data provided here. Discometra is mainly distinguished from all other genera of Himerometridae by its internal coelomic canals located near the aboral surface of the radials.

\section{Geographical distribution}

From southeastern France (this study) to northern and central Italy (Noelli 1900; Airaghi 1904; Albus 1930), central Europe and Poland (Sieverts-Doreck 1961; Radwańska 1987) as well as Algeria (Pomel 1885-1887) and possibly Egypt (cited by Fourtau 1920 but without illustration), in the Early and Middle Miocene.

\section{Included species}

Discometra eggenburgensis (Schaffer, 1912), D. luberonensis sp. nov., D. michelottii (Noelli, 1900), D. rhodanica (Fontannes, 1877) and D. speciosa (Pomel, 1885).

\section{Discometra luberonensis sp. nov. urn:1sid:zoobank.org:act:2C82EC72-FEDC-4BCB-9716-88EEFDB0146D}

Fig. 2A-F

\section{Diagnosis}

Robust species with arms up to 60 in number. Centrodorsal a rounded pentagonal, flattened, truncated cone; basal diameter up to $14.3 \mathrm{~mm}$; aboral pole cirrus-free, flattened and slightly depressed, smooth or very slightly granular, reaching $2 / 3$ of centrodorsal diameter. Cirrus sockets in 2-3 irregular marginal rows. Cirri XXX-L of up to at least 30 never higher than wide cirrals, $27.5 \mathrm{~mm}$ long. Arm pattern with Ibr2ax, IIbr1-2 3+4ax; br1-2ax frequent up to fifth brachitaxis; ligamentary synarthry at br1-2; multiradiate syzygy at br $3+4$; very oblique muscular synarthries in proximal part of arms.

\section{Etymology}

The epithet refers to the Massif du Lubéron, a major mountain range in the Provence area where the specimens on which the description is based were collected. Lubéron is part of the greater administrative area (Région) called Provence-Alpes-Côte d'Azur in the southeast of France.

\section{Material examined}

\section{Holotype}

FRANCE • SE France, Vaucluse, Bassin d'Apt, Ménerbes-Lacoste Plateau; MHNL 20.062682.

\section{Paratypes}

FRANCE • same collection data as for holotype; MHNL 20.056148, 20.056151.

\section{Locus typicus}

"Calcaire de Ménerbes" (Demarcq 1970), facies with large pectinids (Gigantopecten restitutensis), quarries in Ménerbes-Lacoste Plateau (Bassin d'Apt, Vaucluse, southeastern France), Late Burdigalian.

\section{Description}

Holotype (Fig. 2A-B)

Specimen well exposed aborally, displaying centrodorsal, proximal part of three rays, about ten free arms visible in profile and recurved aborally, five cirri still attached to centrodorsal, and many fragments 
of arms and isolated cirri. Centrodorsal a flattened truncated cone; apex broad, almost flat and smooth, devoid of cirrus sockets; cirrus sockets arranged in 2 to 3 irregular rows. Maximum length of complete attached cirrus $27.50 \mathrm{~mm}$ with 30 cirrals; cirrals subcylindrical; c1-c5 wider than high; following cirrals as high as wide; maximum cirral diameter $1.0 \mathrm{~mm}$, average width of proximal half of cirri $2.0 \mathrm{~mm}$, most frequent height of cirrals about $1 \mathrm{~mm}$; terminal claw slightly curved and about twice as long as preceding segment. Radial circlet hidden. Arms divided 4 or 5 times; Ibr2 always axillary; secundibrachitaxes IIbr1-2 3+4ax (4 cases), IIbr undivided (1); pattern observed in the following brachitaxes: IIIbr1-2ax (5), IVbr 1-2ax (4), IVbr 1-2 3+4ax (1), IVbr undivided (1), Vbr1-2ax (2), Vbr1-2 then broken (2), Vbr1 $2+34 \ldots$ (1), VIbr1-2 3+4... (2), estimated total number of arms close to 60 . Non-muscular (ligamentary) articulations: ligamentary synarthry at 1-2 and syzygy with multiradiate crenularium at $3+4$ (most often ankylosed at IIbr3+4); syzygies or synostoses irregularly arranged along free arms, separated by 4 to 8 muscular synarthries; br1-9 more or less rectangular, following brachials wedge-shaped. Maximum primibrachial width $7.10 \mathrm{~mm}$; maximum primibrachitaxis length $6.30 \mathrm{~mm}$; Ibr2ax height $3.42 \mathrm{~mm}$; secondibrachial width $4.90 \mathrm{~mm}$; IIbr1-2 height $3.35 \mathrm{~mm}$; IIbr1-2 3+4ax maximum length $6.25 \mathrm{~mm}$; IIIbr1-2 width $3.50 \mathrm{~mm}$, height $3.35 \mathrm{~mm}$; maximum height of tertibrachial axillary $2.0 \mathrm{~mm}$; average width of proximal half of distalmost free arm $2.65 \mathrm{~mm}$; longest isolated fragment of free arm $38 \mathrm{~mm}$ with 26 brachials; maximum length of an attached free arm $50.0 \mathrm{~mm}$. Preserved pinnules rare, proximal part of $\mathrm{P}_{\text {II }}$ robust, composed of more or less squarish segments; more distal part of proximal pinnule getting thinner and flexible with relatively short pinnulars (less than twice as high as wide).

\section{Paratypes}

Specimen MHNL 20.056148 (Fig. 2C-D) with largest centrodorsal diameter, aboral cirrus-free depression flat and very slightly granular; about 30 cirri preserved around centrodorsal hiding proximal part of crown; complete cirrus with 25 cirrals, length $26 \mathrm{~mm}$, longest cirrus fragment $27 \mathrm{~mm}$ with 28 cirrals. Specimen MHNL 20.056151 (Fig. 2E-F) with most flattened centrodorsal, aboral surface flat and smooth with two small pits; only $2 / 3$ of crown preserved, one brachitaxis visible, with same pattern as holotype; visible arms 38, allowing an estimated total number close to 60 .

Discometra rhodanica (Fontannes, 1877)

Figs 3E, 4A, 5A-B, 6

Eugeniacrinus ? rhodanicus Fontannes, 1877: 669.

Antedon meneghinianus Fontannes, 1880: 412-413, pl. 2, fig. 11a-c.

Antedon rhodanicus - Fontannes 1880: 410-412, pl. 2, fig. 10a-c. - de Loriol 1897: 121-124, pl. 4, fig. 8 (non 9-10). — Nicolas 1897: 131-132, fig. 6; 1898: 398-399, 402-404, fig. 1. — Airaghi 1904: 44-45, figs 14-15. — Schütze 1904: 156-162, pl. 2, figs 4-5. — Albus 1930: 291-292, pl. 11, figs 5,7 .

Discometra rhodanica - Gislèn 1924:180-182. — Biese \& Sieverts-Doreck 1939: 106-107. — SievertsDoreck 1961: 110-117, 124, text fig. 2. - Rasmussen 1978: T890, fig. 593-4a.

Antedon cf. rhodanicus - Valette 1928: 31-34, fig. 5.

Discometra meneghiniana - Biese \& Sieverts-Doreck 1939: 105.

non Antedon rhodanica - Vadasz 1915: 89-90, pl. 7, figs 24-26.

non Discometra rhodanica - Rasmussen 1978: T890, fig. 593-4b-c. — Hess \& Messing 2011: 107, fig. 52-3a-d.

\section{Emended diagnosis}

Species known only from its calyx (centrodorsal + radial circlet). Centrodorsal hemispherical, often more flattened in large specimens, diameter can reach $14 \mathrm{~mm}$; lateral surface with large cirrus sockets arranged in up to 3 irregular rows, each at bottom of a more or less marked depression; aboral pole depressed, conical in smaller (young) specimens (to $1 / 3$ maximum centrodorsal diameter) and bordered 

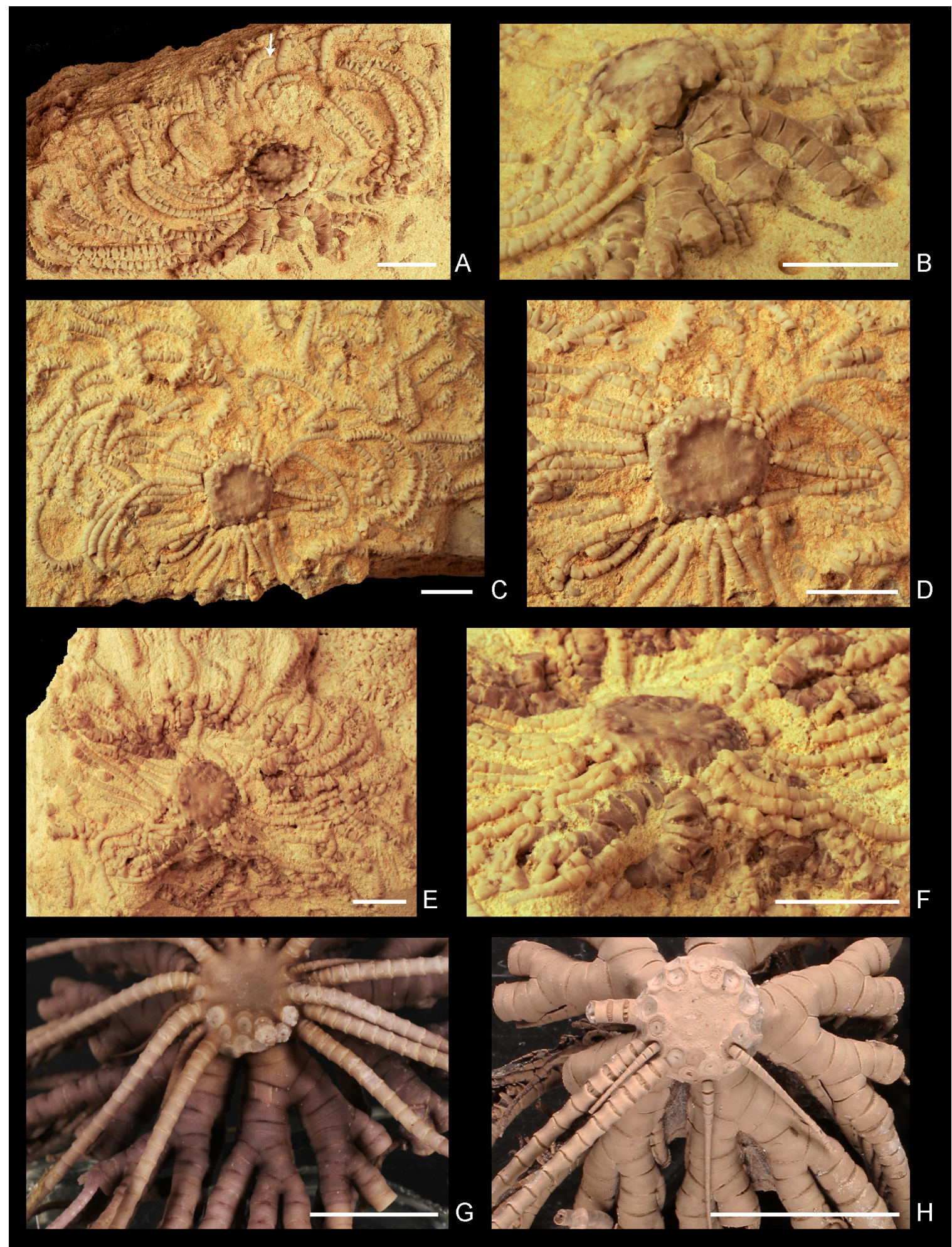

Fig. 2. Aboral view of the proximal crown and centrodorsal in three genera of Himerometridae A.H. Clark, 1908. A-F. Discometra luberonensis sp. nov., Late Burdigalian of Ménerbes-Lacoste Plateau. A-B. Holotype (MHNL 20.062682). C-D. Paratype (MHNL 20.056148). E-F. Paratype (MHNL 20-056151). G-H. Extant species of Himerometridae from western Pacific. G. Himerometra robustipinna (Carpenter, 1881) (MNHN-IE-2012-862). H. Heterometra savignii (Müller, 1841) (MNHN-IE-2016-1381). Scale bars: $A-G=10 \mathrm{~mm} ; \mathrm{H}=5 \mathrm{~mm}$. 
by smaller apical cirrus sockets arranged in two irregular rows; apical depression becoming wider (to $2 / 3$ maximum diameter) and deeper with increasing centrodorsal diameter and with numerous radial grooves.

\section{Material examined}

Neotype

FRANCE • 1 calyx; Bouches du Rhône, Notre-Dame du Château near Saint-Etienne-du-Grès; MASR 2020.5011 (figured by de Loriol 1897: fig. 8).

\section{Other material}

FRANCE • 1 calyx; Gard, Les Angles; UCBL 200025a • 2 calices; same collection data as for preceding; MRA 3.000.348, 3.000.349 • 1 centrodorsal; same collection data as for preceding; UCBL 200025b • 3 calices; Vaucluse, Caumont-sur-Durance, Picabrier; MHNL 20.062686, 20.062687, 20.062688.

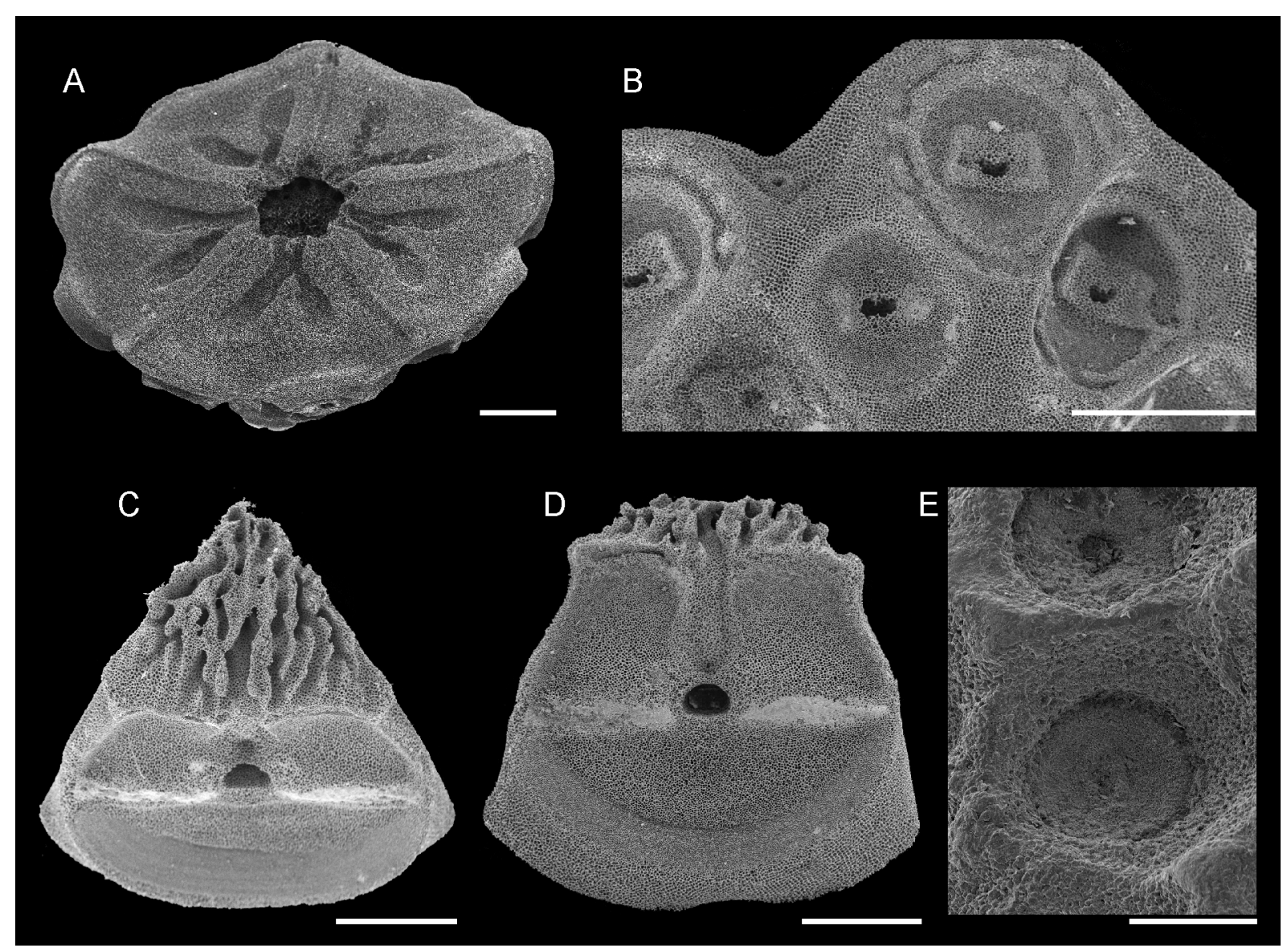

Fig. 3. Centrodorsal and radials in Himerometridae A.H. Clark, 1908. A-D. Himerometra robustipinna (Carpenter, 1881) (MNHN-IE-2012-862). A. Adoral side of centrodorsal. B. Cirrus sockets on lateral face of centrodorsal. C-D. Radials. C. Adoral view showing vermiculate grooves on inner face. D. Distal articular facet. E. Discometra rhodanica (Fontannes, 1877) from Picabrier (MHNL 20.062687), cirrus sockets on centrodorsal. Scale bars: A-D $=1 \mathrm{~mm}$; E $=0.5 \mathrm{~mm}$. 


\section{Locus typicus}

Late Burdigalian, facies with Chlamys praescabriuscula (Fontannes, 1878), near Bollène (Vaucluse, southern France).

\section{Description}

\section{Neotype}

Extensive investigations in the collections of MHNL and MRA to retrieve the specimens used by Fontannes (1880) to describe D. rhodanicus and D. meneghinianus have been unsuccessful. They can be considered lost. Moreover, the locality from which they were collected, now located in an urbanized area, has now become inaccessible. The specimen illustrated by de Loriol (1897: fig. 8) from the Late Burdigalian of Notre-Dame du Château (east of Saint-Etienne du Grès), an outcrop still accessible, is housed in the collection of the Musée des Alpilles in Saint-Rémy de Provence (MASR 2020.5011). We designate this specimen as the neotype (Fig. 5A-B). Although smaller, its good preservation and its characters are similar to those of the specimen illustrated by Fontannes (1880: pl. 2, fig. 10a-c). This specimen consists of a hemispherical centrodorsal and radial circlet. Its dimensions are given in Table 2. The aboral surface of the centrodorsal (Fig. 5A) shows a marked depression surrounded by small apical cirrus sockets (diameter $<0.4 \mathrm{~mm}$ ) partially worn out or biocorroded. The lateral surface is covered with larger cirrus sockets (diameter 0.5 to $0.9 \mathrm{~mm}$ ) more or less oval and hollow; flattened socket floors sometimes displaying a roughly rectangular, low transverse ridge (Fig. 5B, arrow) like in extant Himerometridae (Fig. 3B). These larger cirrus sockets are arranged in up to three irregular rows. The maximum diameter of the radial circlet is much smaller than that of the centrodorsal (ratio 0.82). Centrodorsal height almost equals that of the radial circlet. Radial distal articular facet is almost entirely occupied by ligamentary areas, while muscular areas are comparatively inconspicuous. Its geometry is similar to that observed in Himerometra (Fig. 3D). Irregular radiating grooves can be seen on the walls of the central adoral cavity, which is partially filled with sediment. They correspond to the vermiculate grooves reported above in the extant species of Himerometridae (Fig. 3C).
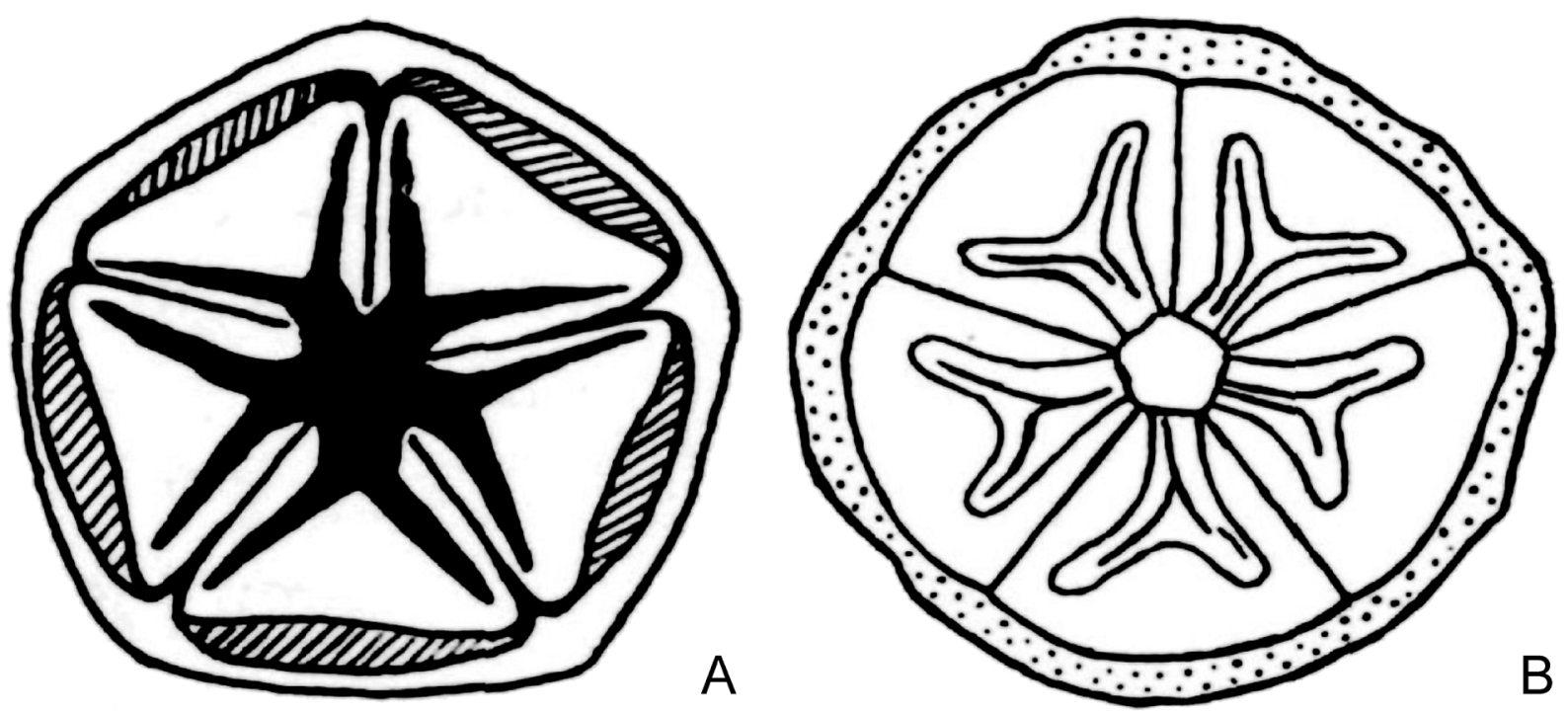

Fig. 4. Cross sections near aboral surface of radial circlet showing Y-shaped coelomic canals in the genus Discometra Gislèn, 1924. A. Discometra rhodanica (Fontannes, 1877). B. Discometra eggenburgensis (Schaffer, 1912). Modified from Sieverts-Doreck (1961) in which A was modified from Fontannes (1880). 


\section{Calices from the Picabrier deposit at Caumont-sur-Durance}

Three calices illustrate morphological changes during growth (Fig. 6). Centrodorsal diameter of the smallest specimen (MHNL 20.062688) is hemispherical, $7.7 \mathrm{~mm}$ across (Fig. 6B), with an aboral face similar to that of the neotype. Centrodorsal of the largest specimen (MHNL 20.062686) is more discoidal, $12 \mathrm{~mm}$ across (Fig. 6A); its aboral depression deeper, $2 / 3$ of centrodorsal diameter; apex completely devoid of cirrus sockets and covered by numerous radial grooves, as in one of the specimens illustrated by Fontannes (1880) (Fig. 4A). Cirrus sockets more or less circular, slightly concave and well delineated, and each located at the bottom of a well-marked depression (Fig. 3E). These depressions become almost contiguous, separated by fragile, often worn out crests. Centrodorsal of specimen MHNL 20.062687 is $9.9 \mathrm{~mm}$ across; specimen shows an intermediate morphology (Fig. 6C-D).

\section{Specimens from other sites}

Most of the other specimens examined were collected in the Rhône-Provence basin by one of us (MP) and are represented by centrodorsals only or centrodorsal and radial circlets, often worn out or biocorroded. Nevertheless, some characters of the calyx, such as degree of centrodorsal flattening, broadening and deepening of aboral cirrus-free depression, centrodorsal/ radial circlet height ratio, and flaring of adoral cavity delimited by the radial circlet, are still visible and prove to be very variable (Table 2). The ancient quarries of Les Angles, now inaccessible, provided many specimens partly described by Nicolas (1898). Those that we have found in older collections, including the largest known specimens (UCBL 200025a, MRA 3.000.348, MRA 3.000.349), are worn out and do not allow detailed observation.

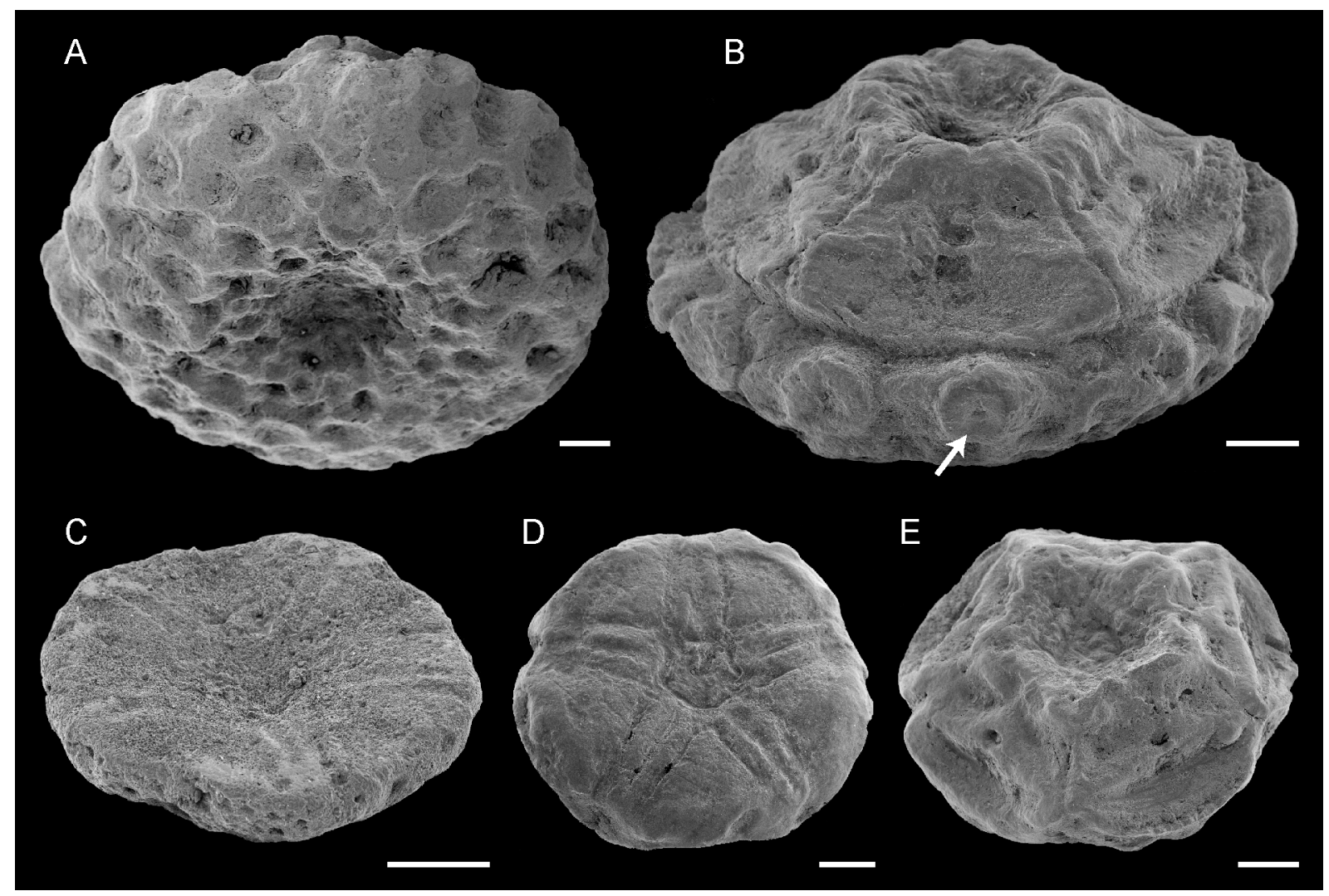

Fig. 5. Late Burdigalian specimens attributed to Discometra rhodanica (Fontannes, 1877) by de Loriol (1897). A-B. Neotype of $D$. rhodanica from Notre-Dame du Château (MASR 2020.5011). A. Oblique aboral view of centrodorsal. B. Oblique adoral view of calyx (arrow $=$ sub-rectangular low ridge). C-E. Unidentified Comatulidae Fleming, 1928. C. Adoral face of a centrodorsal from Entrechaux 'Ferme Pie' (MHNL 20.062689). D-E. Radial circlet from Notre-Dame du Château (MASR 2020.5021). Scale bars $=1 \mathrm{~mm}$. 


\section{Remarks}

Gislén (1924) pointed out the strong affinities between D. rhodanica, D. eggenburgensis and D. meneghiniana (Fontannes, 1880). Discometra meneghiniana is only known from the single calyx described by Fontannes (1880: pl. 2, fig. 11) and considered lost. It was collected from the same outcrops as the holotype of $D$. rhodanica. Fontannes's figure suggests that this specimen is strongly worn out; in particular the aboral depression of the centrodorsal displays an abnormally regularly circular appearance. It nevertheless falls within the field of variation of the species. We consider it to be a junior synonym of D. rhodanica.

\section{Discussion}

\section{Genus Discometra Gislén 1924}

Confirming the pioneering observations of Fontannes (1880) on the presence of Y-shaped coelomic canals in Discometra, Sieverts-Doreck (1961) transferred this genus to Himerometridae. Rasmussen (1978) and Hess \& Messing (2011) adopted the same view.

However, Sieverts-Doreck (1961) had pointed out that the two specimens from Notre-Dame du Château attributed to $D$. rhodanica by de Loriol (1897: figs 9-10) could not belong to family Himerometridae. From these two specimens, we were successful in locating the specimen illustrated in fig. 9 only. This specimen consists of the radial circlet, which shows on its well-preserved aboral face traces of five rod-

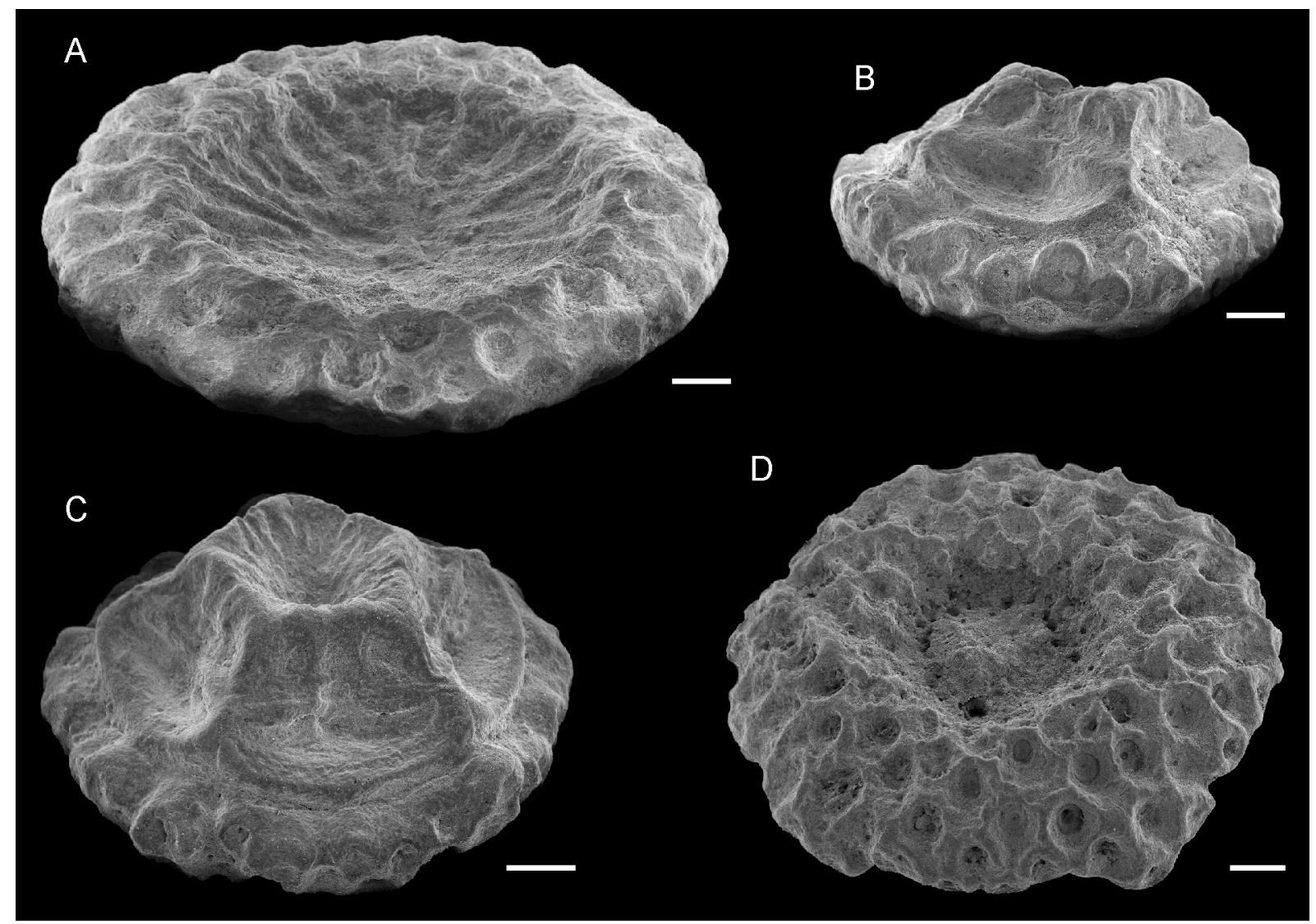

Fig. 6. Calices of Discometra rhodanica (Fontannes, 1877) from Picabrier. A. Aboral oblique view of centrodorsal, largest specimen (MHNL 20.062686). B. Adoral oblique view, smallest specimen (MHNL 20.062688). C-D. Specimen of intermediate size (MHNL 20.062687). C. Adoral oblique view. D. Aboral oblique view. Scale bars $=1 \mathrm{~mm}$. 
shaped basals (Fig. 5D). A corresponding structure is present on the adoral face of an isolated centrodorsal collected near Entrechaux (Ferme Pie) (Fig. 5C). Rod-shaped basals are absent in the superfamily Himerometroidea to which Himerometridae belongs (sensu Hess \& Messing 2011). In addition, the distal articular facet of the radials has small but conspicuous and clearly delimited muscular areas and triangular interarticular ligament fossae. In the specimen attributed by Vadasz (1915: pl. 7, figs 24-26) to D. rhodanica, the distal articular facet of radials exhibits these same characters, which are incompatible with an attribution to Himerometridae according to Taylor et al. (2017). Unfortunately, Hess \& Messing (2011: fig. 52-3a-d) used figures from these two specimens to illustrate the genus Discometra.

In calices from the Rhône-Provence Miocene basin, the main quantitative characters vary mainly with size within each site, but not when considering all the sites together. The ratios indicate a large variability independent of size (Table 2). This result suggests the influence of local environmental conditions. However, large specimens exhibit a marked tendency towards flattening of the centrodorsal and extension of the aboral cirrus-free apical depression. Regarding this variability, the quantitative data are too sparse to draw taxonomic conclusions. Only the qualitative characters of the centrodorsal aboral depression allow us to distinguish two species.

Jagt et al. (2002) recognized five species (Discometra eggenburgensis, D. meneghiniana, D. michelottii, $D$. rhodanica and D. speciosa) of Cenozoic feather stars attributed to the genus Discometra, among which $D$. meneghiniana is here considered to be a junior synonym of $D$. rhodanica (see below).

\section{Discometra luberonensis sp. nov.}

Two genera of extant Himerometridae have a large number of arms: Heterometra with up to 48 arms and Himerometra, which reaches about 60 arms as in D. luberonensis sp. nov. Himerometra displays well separated primibrachitaxes (Fig. 2G), and tertibrachitaxes are of 2 brachials only. Heterometra has brachitaxes of 2 or 4 brachials and primibrachitaxes in lateral contact as in D. luberonensis sp. nov. (Fig. 2B), or separated (Fig. 2H) as in Himerometra. The centrodorsals of D. luberonensis sp. nov. differ from those of $D$. rhodanica and D. eggenburgensis in having a less hemispherical general shape, an aboral depression devoid of cirrus sockets, and a flatter and smoother aboral depression devoid of both cirrus sockets and radial grooves (Fig. 2B, D, F) as is common in other extant Himerometridae (Fig. 2G-H). Attribution of this new species to the genus Discometra needs to await confirmation of the presence of internal coelomic canals near the proximal surface of the radials.

\section{Discometra rhodanica (Fontannes, 1877)}

By comparing calices from other sites with the growth series from Picabrier, it appears that the neotype from Notre-Dame du Château and the holotype from Bollène fit into this sequence in size and shape. The holotype of $D$. meneghiniana and the large specimens from Les Angles have their aboral depression moderately developed despite their large size. Some specimens of $D$. eggenburgensis (Sieverts-Doreck 1961: figs 3a, 4) have a broad aboral depression with radiate grooves, but more discrete than those observed in the largest specimen from Picabrier. In view of the morphological variations in D. eggenburgensis described by Sieverts-Doreck (1961) and our observations on D. rhodanica, we do not have a robust discriminating character to distinguish the two species based on the calyx alone. Pending additional data on the crown and cirri in the two species, we suggest that the distinction between them should be temporarily maintained.

\section{Acknowledgements}

For access and loan of the specimens studied here, our thanks go to Didier Berthet (Centre "Louis Lortet" de conservation et d'étude des collections, Musée des Confluences, Lyon), Emmanuel Robert (Service des collections, Sciences de la Terre, Université Claude Bernard, Lyon I), Pierre Moulet 
ELÉAUME E. et al., A new species of feather star (Echinodermata: Crinoidea) from the Miocene

(Musée Requien - Musée d'Histoire naturelle - Avignon), and Virginie Olier (Musée des Alpilles, Saint-Rémy de Provence). The following small MNHN funding sources helped get together all pieces of this work: Actions Transversales du Muséum "Formes possibles, Formes réalisées", "Biodiversité actuelle et fossile. Crises, stress, restaurations et panchronisme: le message systématique", "Taxonomie moléculaire: DNA Barcode et gestion durable des collections". We also wish to thank Géraldine Toutirais who greatly facilitated our work at the Plateau Technique de Microscopie Électronique et de Microanalyses du Muséum national d'histoire naturelle in Paris. We would like to warmly thank Ben Thuy and Charles Messing for their help to improve the original manuscript.

\section{References}

Airaghi C. 1904. Echinodermi miocenici dei dintorni di S. Maria Tiberina (Umbria). Atti dell'Accademia delle Scienze di Torino 40: 43-54.

Albus L. 1930. Nuove ricerche sui crinoidi miocenici della Collina di Torino. Bollettino della Società geologica italiana 49 (2): 279-296.

Besson D. 2005. Architecture du bassin rhodano-provençal miocène (Alpes, SE France). Relations entre déformation, physiographie et sédimentation dans un bassin molassique d'avant-pays. $\mathrm{PhD}$ thesis, École des Mines, Paris.

Biese W. \& Sieverts-Doreck H. 1939. Crinoidea caenozoica. In: Quenstedt W. (ed.) Fossilium Catalogus I. Animalia pars 80: 1-151. W. Junk, s'Gravenhage.

Bongrain M. 2013. Les accumulations de Gigantopecten restitutensis (Fontannes, 1884) (Mollusca: Bivalvia: Pectinidae) dans le Burdigalien supérieur des carrières de Ménerbes et de Lacoste (Vaucluse, bassin d'Apt, SE France): analyse et hypothèse explicative. Geodiversitas 35 (3): 607-628.

https://doi.org/10.5252/g2013n3a5

Clark A.H. 1909. A revision of the crinoid families Thalassometridae and Himerometridae. Proceedings of the Biological Society of Washington 22: 1-22.

Clark A.H. 1915. A monograph of the existing crinoids, Vol. 1. The comatulids, pt. 1. Bulletin of the United States National Museum 82: 1-406. https://doi.org/10.5962/bhl.title.1326

Clark A.H. 1918. The unstalked crinoids of the Siboga expedition. In: Siboga-Expeditie 42b: 1-300. E.J. Brill, Leiden. https://doi.org/10.5962/bhl.title.11317

Demarcq G. 1970. Étude stratigraphique du Miocène rhodanien. Mémoires du Bureau de Recherches géologiques et minières 61: 1-257.

Demarcq G. 1984. Importance des mégafaunes marines benthiques dans l'évolution paléothermique de la Méditerranée au Néogène. Annales de Géologie des Pays helléniques 32: 87-95.

Fontannes C.F. 1877. Les terrains tertiaires supérieurs du Haut Comtat-Venaissin. Annales de la Société d'Agriculture, Histoire naturelle et Arts utiles de Lyon 4 (9): 571-672.

Fontannes C.F. 1880. Études stratigraphiques et paléontologiques pour servir à l'histoire de la période tertiaire dans le bassin du Rhône. Description de quelques espèces nouvelles ou peu connues. Crinoïdes. Annales de la Société d'Agriculture, Histoire naturelle et Arts utiles de Lyon 5 (1): 410-416.

Fourtau R. 1920. Catalogue des invertébrés fossiles de l'Egypte. Terrains tertiaires, 2. Echinodermes néogènes. Egyptian Geological Survey, Paleontology 4: 1-100.

Gislén T. 1924. Echinoderm studies. Zoologiska bidrag från Uppsala 9: 1-316. 
Hemery L. 2011. Diversité moléculaire, phylogéographie et phylogénie des crinoïdes (Échinodermes) dans un environnement extrême, l'océan Austral. $\mathrm{PhD}$ thesis, Muséum national d'histoire naturelle, Paris.

Hess H. \& Messing C.G. 2011. Comatulida. In: Hess H., Messing C.G. \& Ausich W.I. (eds) Treatise on Invertebrate Paleontology, Part T. Echinodermata 2 (Revised), Crinoidea, Vol. 3: 70-159. University of Kansas Press, Lawrence. https://doi.org/10.17161/dt.v0i0.5392

Jagt J.W.M., Deckers M.J.M. \& Parren J. 2002. Notes on North Sea Basin Cainozoic echinoderms, Part 1. Miocene comasterid crinoids from central Limburg, the Netherlands. Cainozoic Research 1: 83-90.

Joleaud L. 1907. Géologie et Paléontologie de la Plaine du Comtat et de ses Abords. Description des Terrains néogènes, Fascicule I. F. Seguin, Avignon.

Loriol P. de 1897. Description de quelques echinodermes. Bulletin de la Société géologique de France 3 (25): $115-129$.

Nicolas H. 1897. Étude sur les terrains Tertiaires des environs d'Avignon. Le Miocène. Mémoires de l'Académie du Vaucluse 16: 60-152.

Nicolas H. 1898. Études des terrains des environs d'Avignon. Note complémentaire. Association française pour l'Avancement des Sciences, Comptes rendus, Congrès de Saint-Etienne (1897) 2 : 393413.

Noelli A. 1900. Contribuzione allo studio dei crinoidi terziari del Piemonte. Atti della Società italiana di Scienze naturali 39: 19-49.

Pellat E. 1897. Sur l'assise terminale de l'étage Burdigalien supérieur près des Angles (Gard) et près de Saint-Etienne-du-Grès (Bouches du Rhône). Bulletin de la Société géologique de France 3 (25): $111-114$.

Philippe M. 1974. Découverte de gisements à faune burdigalienne dans les «Marnes bleues de Faucon» à Entrechaux (Vaucluse) et à Mollans (Drôme). Bulletin mensuel de la Société Linnéenne de Lyon 43 (1): 5-8. https://doi.org/10.3406/linly.1974.10096

Philippe M. 1998. Les échinides miocènes du bassin du Rhône: révision systématique. Nouvelles Archives du Muséum d'Histoire naturelle de Lyon 36: 3-441.

Pomel N.A. 1885-1887. Paléontologie ou Description des Animaux fossiles de l'Algérie. Zoophytes. $2^{e}$ Fascicule. Échinoderms. $1^{\text {re }}$ Livraison. Adolphe Jourdan, Alger.

Radwańska U. 1987. Free-living crinoids from the Korytnica Clays (Middle Miocene, Holy Cross Mountains, Central Poland). Acta Geologica Polonica 37: 113-129.

Rasmussen H.W. 1978. Articulata. In: Moore R.C. \& Teichert C. (eds) Treatise on Invertebrate Paleontology, Part T. Echinodermata 2, Crinoidea Vol. 3: T813-1027. Geological Society of America, Boulder, CO, and The University of Kansas Press, Lawrence, KS. https://doi.org/10.17161/dt.v0i0.5649

Schütze E. 1904. Die Fauna der schwäbischen Meeresmolasse. 1. Teil: Spongien und Echinodermen. Jahreshefte des Vereins für vaterländische Naturkunde in Württemberg 60: 147-198.

Sievertz-Doreck H. 1961. Zur Kenntnis der Crinoidengattung Discometra (Comatulida, Mariametrina) im Miozän des Wiener Beckens. Annalen des naturhistorichen Museums Wien 64 (1960): 105-126.

Strimple H.L. \& Mapes R.H. 1984. Comatulid crinoids from the Jacksonian (Eocene) of Louisiana. Journal of Paleontology 58 (3): 789-792.

Summers M.M. \& Rouse G.W. 2014. Phylogeny of Myzostomida (Annelida) and their relationships with echinoderm hosts. BMC Evolutionary Biology 14 (1): 1-27. https://doi.org/10.1186/s12862-014-0170-7 
ELÉAUME E. et al., A new species of feather star (Echinodermata: Crinoidea) from the Miocene

Taylor K.H., Rouse G.W. \& Messing C.G. 2017. Systematics of Himerometra (Echinodermata: Crinoidea: Himerometridae) based on morphology and molecular data. Zoological Journal of the Linnean Society 181: 342-356. https://doi.org/10.1093/zoolinnean/zlx009

Ulysse J. 1968. Contribution à l'étude des gisements miocènes de Caumont et de Bonpas (Vaucluse). Diplôme d'études supérieures spécialisées (DESS) de Géologie, Université Lyon I, Lyon.

Vadasz M.E. 1915. Die mediterranen Echinodermen Ungarns. Geologica Hungarica 1 (2): 79-254.

Valette D.A. 1928. Note sur quelques antédons du Burdigalien supérieur des Angles (Gard). Bulletin de la Société géologique de France 4 (28): 23-35.

Manuscript received: 17 June 2020

Manuscript accepted: 14 October 2020

Published on: 29 December 2020

Topic editor: Christian de Muizon

Desk editor: Radka Rosenbaumová

Printed versions of all papers are also deposited in the libraries of the institutes that are members of the EJT consortium: Muséum national d'histoire naturelle, Paris, France; Meise Botanic Garden, Belgium; Royal Museum for Central Africa, Tervuren, Belgium; Royal Belgian Institute of Natural Sciences, Brussels, Belgium; Natural History Museum of Denmark, Copenhagen, Denmark; Naturalis Biodiversity Center, Leiden, the Netherlands; Museo Nacional de Ciencias Naturales-CSIC, Madrid, Spain; Real Jardín Botánico de Madrid CSIC, Spain; Zoological Research Museum Alexander Koenig, Bonn, Germany; National Museum, Prague, Czech Republic. 